\title{
Contemporary Value of Marx's Communication Theory
}

\author{
Li XU \\ School of Marxism of Wuhan Business University \\ Wuhan China \\ 1546687173@qq.com
}

\begin{abstract}
In the new century, world communication has been changing spatial structure and time rhythm of human beings, and the contemporary historical pattern featuring frequent communication, high population flow, close interdependence and fast pace is being formed. Contemporary value of Marx's communication theory is expounded in this paper from four angles: development of contemporary historical materialism, contemporary western post-modern communication concept, and formation of $C$ hinese social development theory and realization of all-round human development. It's sufficiently proved that development opportunities can be extended only when various countries over the world take an active part in world communication. Only in this way can the latest and the most advanced science and culture in the contemporary world be absorbed so as to directly transcend the present development phase.
\end{abstract}

Keywords-Marx; Communication Theory; Theoretical Value; Historical Materialism; Western Philosophy

\section{SigNiFICANCE OF MARX's COMMUNICATION THEORY TO CONTEMPORARY HISTORICAL MATERIALISM}

Marx's communication theory endows historical materialism contemporary contents, contemporary significance and contemporary forms. From the end of the 20th century to the beginning of the 21st century, "globalization" has become one of terms which are used most frequently in the fields like economy, politics, society, laws and ecology. Globalization theory derives from The German Ideology by Marx and Engels. In The German Ideology, they not only systematically expounded historical materialism and communication concept for the first time but also proposed original and forwardlooking world view of history. In other words, they discussed about radical problems and central problems of globalization at the earliest and explained main growth points and basic ideas of globalization theory. "Contemporary globalization refers to objective historical course and trend of all-round communication and mutual influence manifested in contemporary people's social life, which spans boundaries between countries and between regions, within a global scope, and it is also a transformation process of human activities from a sealed world based on blood relationships and race relations into a socialized world as well as a transformation process from small-scale natural economy-based society into large-scale market economy-based society. However, by its nature, it is still capitalist globalizing movement. Globalization history is namely a process of capital continuously shaking off regional limitations and stepping towards the globe. [1]

Economic globalization belongs to the category of communication in essence. Essence of economic globalization is not integration of production mode but integration of communication mode. On the surface, the place where production elements like capital, technology and product flow is usually hidden with communication activities of human beings. What it does is to move factories to various countries and regions in the world and distribute existing commodities to the whole world. Transnational corporations have been founded in various countries and regions in the globe, and all of these are realized through communication. Global economic communication is the communication of all labor products, labor capacities and labors based on value exchange.

\section{SignificAnCE OF MARX COMMUNICATION THEORY TO CONTEMPORARY WESTERN PHILOSOPHY}

Marx communication theory has a positive influence on contemporary western post-modern communication concept. Habermas is one of the figures in contemporary western world who study communication theory. Habermas explains social behaviors and interpersonal communication of human beings with "rational linguistic paradigms", lays the emphasis on inter-subjects formed by dialogue process between people and spiritual relations like ideology, linguistic symbols and moral value, and highlights inter-subject spiritual communication, fusion of visual fields, moral sympathy and other communication relations as well as dialogue forms on the precondition that linguistic effectiveness is mutually recognized. Communication activity theory of Habermas can be divided into two parts: activity theory which expounds relationships of communication activities with three worlds (objective, social and subjective); social theory which expounds social rationality, modernization and colonization.

Communication activity theory of Habermas has synthesized some radical problems appearing in contemporary society from the angle of basic theory. Many enlightening ideas have been proposed. The theory has stirred up great reaction in international society and played a significant role, but it also has some major problems. A fundamental difficulty is mixing between understanding and consensus. Habermas defined communication activities as activities to reach understanding. During expounding process, he regarded "understanding” and "consensus" as the same, "understanding means that 
participants in the communication activity reach a consensus”. [2]Actually, for communication or language communication, "understanding" is a very weak requirement while "consensus" is a stronger requirement. "Understanding" is mainly related to utterance and it requires mastering significance of verbal behaviors in essence. However, "consensus" is related to value and it requires defining the same practical standpoint. Therefore, "understanding" is not identical with "consensus". People may easily reach mutual understanding during the communication activity, but they may not reach a consensus.

Of course, we should rationally understand that social communication theory of Habermas based on language ontology replaces "communication paradigm” with Marx's "production paradigm". The social communication theory is not only based on false explanation of Marxist basic viewpoints but also on his one-sided, romantic and ideal communication mode. When explaining Marxism, Habermas usually criticizes, modifies and replaces Marx's historical materialism with selfdesigned theoretical framework. Therefore, in his conception of "reconstruction of historical materialism", correctional complementation between economism and practical philosophy in Marxism researches is always contained. Habermas understood that function and position of communication are correct. To some degree, he recovered organic contents of Marxist philosophy. He saw importance of living world and emphasized important effect of verbal behaviors in social life. However, Habermas was opposed to one-sided idea about subjective \& objective bodies in labor and class struggle. But he finally was stuck in language-centered inter-subject onesidedness himself. This communication theory, which attempts to participate in contemporary social life and promote social development through people's internal activities like subjective activities such as learning, thinking and debating, neglects severe ecological problems faced by contemporary society, development relation between society and external natural social economy, social culture occupied by social nature owned by individuals as well as historical limitation of social communication decided by history of labor and classes and possibility of non-language communication (like war, material communication, etc.), and consequently, its theoretical conception steps towards illusory "Utopia”. Because the only foundation of social development and evolution is material production activity but not language. Historical materialism takes social material production activity and material communication relationship as fundamental starting point to study social development. Only by taking investigation on history of material production mode as starting points of its all theories can it be really scientific. If the most fundamental communication relation—social production relation-is stripped off, definite and reasonable answers can be given to neither interpersonal relations nor international relations. To sum up, communication idea of Habermas is nothing but contemporary development of Marx's communication concept.

Materialism of communication practice, which will the main development trend of Chinese philosophy in the 21st century, will provide an active and novel idea for brand-new integration of Marxist philosophy and contemporary western philosophy.

\section{SIGNIFICANCE OF MARX'S COMMUNICATION THEORY TO HUMAN DEVELOPMENT}

In terms of the relation between communication and human development, Marx explored into this problem in many of his works. In Economic \& Philosophic Manuscripts of 1844, The German Ideology, The Communist Manifesto, Economic Manuscripts in 1857-1858 and Das Kapital, Marx paid special attention to relation between communication and human development when expounding communication.

All-round human development is the final goal of social development. Communication universality and all-round human de velopment are closely related and indivisible and they promote each other and enjoy mutual development. On the one hand, communication is an essential condition of all-round human development. To survive, human beings can't make it without production activities; continuous development of production activities contributes to more frequent communication activities between people, broader communication scope, wider and wider practical activity scope of human beings and greater and greater degree of freedom in selection. Continuous development of communication has continuously enriched and perfected social relations between people and layers of human needs have been continuously elevated. Meanwhile, ideological and ethical qualities and scientific and cultural qualities have bee improved, and human autonomy, initiative and creativity have obtained free and allround development. On the other hand, all-round human development is an important guarantee for orderly communication. Communication is the most basic mode between different practical subjects, so development degree, development scope and development level of communication relies on development status of human beings. All-round development of human practical activities and all-round completion of social relations have prepared necessary preconditions for general communication; all-round development of human needs is the internal driving force for continuously expanded communication; improvement of human ability and quality and publicity of free personality are important conditions for orderly communication. All in all, communication and human development are under organic unification. Different communication development levels result in different human development degrees; human development status in different periods reflects development degree of human communication to some degree. With daily generalization of communication, all-round human development has turned into reality step by step.

Global economic communication is material basis of allround human development. With globalized productivity development, globalized market economy will certainly lead to global communication. During global economic communication process, social relations, practical activity, comprehensive quality, human needs and free personality have obtained further all-round development. Without global economic communication, human beings can't obtain sufficient, free and all-round development.

Global political communication is a political guarantee for all-round human development. "If exchange of economic forms has defined all-round equality between subjects, then content, 
namely individual materials and physical materials which facilitate people to exchange, defines freedom”. [3]Market economy impacts absolute political institution and political relation and defines and develops modern democratic politics. Political democratization is not only an important symbol of modern society but also a global common political idea, and moreover, it's a necessary condition for realization of human equality and freedom and a political guarantee for publicity of human free personality. Without democracy, there will be no freedom and equality or development of free personality of human beings. All-round human development can be realistic only in global political communication.

Global cultural communication is spiritual strength to realize all-round human development. Global communication is not only economic and political communication but also cultural communication. Global cultural communication provides new opportunities and challenges for ideological and moral construction, promotes transformation of people's production mode and life style and causes change of people's thinking pattern and values so as to improve their ideological and ethical qualities. On the other hand, global cultural communication creates essential conditions for development of education, science \& technology and culture. Global cultural communication makes global communication means of education, science \& technology and culture more convenient with faster communication. The methods of acquiring knowledge are simpler and more flexible, human beings gradually become "intellectuals", and human potential and creativity and abilities in various aspects have obtained comprehensive development, which further boosts all-round human development.

\section{SignificAnCE TO MARX’s COMMUNICATION THEORY TO CHINESE SOCIAL DEVELOPMENT THEORY}

Marx's communication theory endows contemporary social development theory new contents, forms and significance. Mao Tse-Tung thought is the product combining Marxism-Leninism and Chinese revolutionary practice, which mainly solves the problem about how to realize new-democratic revolution and step towards a modern society in a semi-feudal and semicolony country. According to birth and development course of Mao Tse-Tung thought as well as history, experience and significance to Chinese democratic revolution and socialist revolution, it can be seen that communication practice theory is the central philosophy of Mao Tse-Tung thought especially new democracy theory, and Mao Tse-Tung thought is Marxism generated by combining localization of Marxism-Leninism. In works like On New Democracy and The Chinese Revolution and The Chinese Communist Party, Mao Tse-Tung gave profound and accurate explanation to the then China's national conditions. "Emancipating the mind, seeking truth from the facts" is the essence of Deng Xiaoping Theory. Its clear meaning can't be understood if viewpoint of communication practice is shaken off. Viewpoint of communication practice is philosophical foundation of Deng Xiaoping Theory, manifested by his essential mastery of two basic points - reform and opening up —of basic line of the Chinese communist party.
Transition from planned economic system into socialist market economy system is essential transition from single-subject practice pattern into multi-subject communication practice pattern. The key of reform is to make enterprises become true legal subjects in system, and concrete reform scheme has also embodied this philosophical theme. "Socialist market economy is a new communication practice in essence”. [4] According to scientific cognition of nature and opportunities of the new globalization era, Deng Xiaoping believed that policy objective lied in re-constructing global relations between China and the world and completing China's modernization in global communication. All-round opening up of China has obtained astounding achievements, which is an inexorable outcome of transformation of communication practice concept. Therefore, core structure and basic framework of both market economy and open practice are new communication practices which constitute the philosophical foundation for Deng Xiaoping to transcend predecessors and re-construct China's development idea.

\section{CONCLUSION}

In the new century, world communication is changing spatial structure and time rhythm of human beings. With development of productivity and continuous expansion of labor division, communication is increasingly popularized. "The past regional and ethnic self-sufficiency and introverted status is replaced by all-round communication between nationalities and their mutual dependence", "the world is a integral one" and "history" is transformed into "world history".[5]Marx's communication theory is not only of significance to development of contemporary historical materialism but also of positive influence on contemporary western post-modern communication concept and China's social development, and furthermore, it's an important path to realize all-round human development. Opportunities can be expanded for various countries in the world to realize innovation of development road only when they actively participate in world communication. In today's world, globalization is an irreversible trend of the development of, in the face of such trend, any country can't buck the trend for, want to seek more development opportunities and seek the further development of space, must be mutual fusion and mutual cooperation. Seek complementary advantages in cooperation and integration, so as to seek win-win development.

\section{REFERENCES}

[1] Wang Dong, Feng Ziyi, Nie Jinfang. Marxism and Globalization. [M]. Beijing: Peking University Press. 2003. Page 285.

[2] Yao Dazhi. Habermas: Communication Activity Theory and Its Problems. Jilin University Journal Social Sciences Edition. 2000, 6. Page 10.

[3] Marx and Engels. Karl Marx and Frederick Engels, volume 46, No. 1. [M]. Beijing: People’s Publishing House. 1979. Page 197.

[4] Ren Ping. Marx in Contemporary Field of View. [M]. Jiangsu: Jiangsu People's Publishing Press. 2003. Page 268.

[5] Marx and Engels. Selections (Anthologies) of Marx and Engels, Vol. 1 [M]. Beijing: People’s Publishing House. 1972. Page 255. 